\title{
South African Price Changes ANd INFLATION SINCE 1974: A NOTE ON THE TESTING OF INFLATION ACCURACY ${ }^{1}$
}

\author{
Jannie Rossouw \\ SA Reserve Bank and Department of Economics, University of Pretoria \\ Vishnu Padayachee \\ School of Development Studies, University of KwaZulu-Natal
}

\begin{abstract}
As inflation credibility in South Africa records low readings when measured in terms of inflation credibility barometers, this note aims at assessing whether actual price movements provide any grounds for low inflation credibility. It compares the price movements of similar items with the rate of inflation over a period of 32 years, i.e. from 1974 to 2006, and discusses the use of an inflation accuracy indicator to compare estimated price levels adjusted by the rate of inflation and actual price levels. Over the period of comparison no systematic over- or under-reporting of changes in prices in terms of the rate of inflation could be detected and the analysis suggests that little or no basis can be found to justify low inflation credibility. Inflation credibility is more likely than not influenced by the most recent purchasing experiences of consumers. Doubts concerning the accuracy of inflation figures could nevertheless result in the general public concluding that monetary policy aiming at the achievement of an inflation target brings only the pain of high interest rates without the tangible benefits of lower inflation, thereby jeopardising the usefulness of an inflation-targeting monetary policy framework.
\end{abstract}

JEL E31

\section{1}

\section{Introduction}

A paper in an earlier edition of this Journal (Rossouw \& Padayachee, 2007) has shown that inflation credibility in South Africa records low readings when measured in terms of inflation credibility barometers (see also Rossouw \& Joubert, 2005a; or Rossouw \& Joubert, 2005b in this regard). The central finding of the earlier paper was that official inflation figures are often not viewed as accurate indicators of average price increases in the domestic economy. This note assesses whether actual price movements over a period of 32 years provide any grounds for low inflation credibility.

In an attempt to compile a review of literature on the testing of inflation accuracy, it transpired not only that little has been published on this topic, but also that research in this area does not focus on the question whether actual average price increases are reflected accurately by inflation rates over time. The literature available on inflation accuracy focuses mainly on measuring the degree of accuracy of central banks in hitting their official targets in countries following an inflation targeting monetary policy regime (see for instance Albagli \& SchmidtHebbel, 2004; Calderon \& Schmidt-Hebbel, 2003; Mishkin \& Schmidt-Hebbel, 2007; or Roger \& Stone, 2005). One exception is a paper by Gray (2000), who assesses the accuracy of inflation data in south-eastern Europe and observes that accuracy is subject to question in the countries that have emerged from the former Yugoslavia, owing mainly to the use of outdated spending patterns in the weights comprising the inflation basket, since the basket has not been adjusted for increased consumer spending on services. 
The present contribution assesses the accuracy of inflation figures by comparing price estimates of selected items on the basis of historic inflation data over time with actual price levels. It is arranged as follows: Section 2 considers the methodology used in the compilation of this note. Section 3 emphasises difficulties in comparing the historic and current prices of goods and services. In Section 4 actual prices are compared with estimated price levels, thereby showing whether low inflation credibility can be explained in terms of actual prices exceeding estimated prices, calculated on the basis of average price increases according to the rate of inflation. The conclusions follow in Section 5.

\section{2}

\section{Methodological approach}

The aim of this note is to test the hypothesis that changes in the domestic consumer price index (CPI) are a fair reflection of average price increases over time. The purpose of testing the hypothesis is to distinguish between perception and reality concerning the accuracy of inflation data over time (see for instance Rossouw \& Padayachee, 2007) by ascertaining whether prices generally increased in accordance with or at a slower or faster pace than the CPI.

The rate of inflation reports average price increases for an average household during a particular period. Deliberate or accidental measurement errors by the authorities responsible for the compilation of the CPI will imply a divergence between actual price levels and price levels estimated in terms of movements according to the rate of inflation. In such a scenario actual prices will be higher or lower than estimated prices, depending on whether measurement errors resulted in the over- or under-reporting of inflation. This note compares the estimated current prices of selected goods, adjusted in terms of movements in the CPI over the relevant periods of comparison, with their actual prices as at the time of comparison. A review of the literature does not reveal any previous research of a similar nature.

The research methodology can be explained by two practical examples, based on the data used in this note. First, the historic price of an
$800 \mathrm{~g}$ loaf of brown bread was 9c (or R0.09) in October 1974 (detail highlighted in appendix 1). With the CPI of October $1974=100$, CPI in 2006 amounts to 2 463.0. This implies an average annual rate of increase in prices of 10.53 per cent, in other words that prices increased by some 25 times over this period. If the price of bread had increased at this rate, its price estimation for 2006 would have been R2.22. The actual price was R3.69, amounting to an average increase of 12.31 per cent per annum. The rate of increase accordingly exceeded the average rate of increase estimated in terms of the rate of inflation by a considerable margin, or to restate this: the actual price was considerably higher than the estimated price by 2006 .

Secondly, the historic price of $750 \mathrm{ml}$ cooking oil was 46c (R0.46) in October 1974 (detail highlighted in annexure 1). Given the average rate of increase in prices of 10.53 per cent $(25$ times) according to the rate of inflation from that date to 2006 , the estimated price would be R11.33 in 2006. The actual price was R6.99, amounting to an average increase of 8.88 per cent per annum. The rate of increase was accordingly considerably lower than the average rate of inflation.

By applying this methodology to a broad range of products, one can ascertain whether actual prices increased at higher or lower rates than the average rate of change in the CPI. This analysis can also be used to assess adjustments in the relative prices of items. In the example above, the price of a bread was equal to 19.6 per cent of the price of a bottle of cooking oil in 1974 . By 2006 the bread/cooking oil price ratio was 52.8 per cent. This comparison confirms that adjustments in relative prices can sometimes go unnoticed by consumers during periods of sustained high inflation, since all price changes are blamed on inflation, rather than on changes in relative scarcity.

Extensive research on inflation accuracy, covering different periods for the purpose of comparison, is not reported in the literature. Moreover, the literature does not mention any instrument for measuring the results of such research. This note therefore suggests the calculation of an inflation accuracy indicator (IAI) for this purpose. The IAI measures the 
accuracy of average price increases around a reading of zero, with readings above zero indicating that the majority of actual prices were lower than price levels estimated in terms of the rate of inflation. It is calculated by deducting the percentage of prices that increased at a rate higher than the rate of inflation from zero, and adding the percentage of prices that increased at a rate slower than the rate of inflation to the result, so as to provide the IAI reading. The following equations explain the calculation of the IAI:

\section{Estimated price:}

$\widehat{P}$ ice $_{t}=$ Price $_{b} \frac{C P I_{t}}{C P I_{b}}$

Where: $t=$ Time (year) of price estimate

$$
b=\text { Base period }
$$

Example in respect of a 1974 base price:

$$
\widehat{P}_{\text {rice }} \text { 2006 }=\text { Price } \text { I974 } \frac{C P I_{2006}}{C P I_{1974}}
$$

\section{Inflation accuracy indicator (IAI):}

$$
I A I=\left[\left(0-P_{g}\right)+\left(0+P_{s}\right)\right]
$$

Where:

$$
\begin{aligned}
\mathrm{P}_{\mathrm{g}}= & \frac{\sum\left(P_{t}>\hat{P}_{t}\right)}{\text { Total observations }} \times 100 \\
= & \begin{array}{l}
\text { Percentage of total observations } \\
\text { where actual price is higher than } \\
\text { estimated price; and }
\end{array} \\
= & \frac{\sum\left(P_{t}<\hat{P}_{t}\right)}{\mathrm{P}_{\mathrm{s}} \quad} \times 100 \\
= & \begin{array}{l}
\text { Petal observations } \\
\text { where actual price is lower than } \\
\end{array}
\end{aligned}
$$

With $P_{t}=$ Actual price in period $t$ and $\hat{P}_{t}=$ Estimated price in period $t$.

The IAI exhibits certain shortcomings which might limit its usefulness under certain circumstances in its current format. First, in its calculation the same importance (or weight) is allocated to all items, irrespective of their actual weights or importance in the spending basket of an average household. Secondly, the IAI provides no clarity on changes in relative prices over time.
Changes in relative prices influence consumer behaviour, but the IAI is merely a static measure of prices over time and cannot shed any light on changing price structures. Thirdly, it makes no allowance for quality improvements. Despite these shortcomings and the need for its further development, periodic measurement in terms of an IAI will demonstrate a trend between actual price increases and the rate of inflation over any period of comparison, thereby pronouncing on the accuracy of average price increases measured in terms of the rate of inflation.

\section{3}

\section{Difficulties in comparing historic and current prices during over any period of comparison}

The identification and selection of products (other than food ${ }^{2}$ ) and services to use for the purpose of comparing their estimated and actual prices over any period pose various challenges, since goods and services used by an average household have changed considerably with the passage of time. Relative wealth and leisure time of consumers have also improved. This section summarises some of the most obvious changes and challenges.

\subsection{Quality improvements}

Goods and services have undergone numerous quality improvements over the period of comparison referred to in this note, that is, from 1974 to 2006. A discussion of the detail of such improvements is beyond the scope of this analysis. It is sufficient to mention that the true value enhancement of many improvements to goods and services can hardly be expressed in monetary terms. In this note goods and services are, despite quality improvements, assumed to be homogeneous over the periods of comparison, implying that the true value of quality improvements is simply regarded as price increases owing to inflation.

\subsection{Relative scarcity}

The main function of prices is to reflect the relative scarcity of goods and services. Changes 
in relative scarcity should accordingly be reflected in price changes, thereby signalling to consumers that consumption patterns should be amended to reflect such changes. In this note price changes owing to changed relative scarcity are discarded, as such changes cannot be constructed ex post, and all price increases are therefore attributed to an increase in the general price level in the economy.

\subsection{Relative wealth and productivity}

Over the period of comparison, the relative wealth of consumers altered. This can be explained in terms of the work/leisure balance, which is related to the number of hours of work required to purchase a particular item and improvements in productivity. Cox and Alm (1997: 4) explain that it took an average American 30 minutes of labour in 1919 to earn enough to buy a pound (454g) of ground beef, whereas the labour time required decreased to 6 minutes by 1997. Similarly, Marber (2003: 25) states that an average American had to work some 260 hours to purchase a bicycle in 1895 , while it took only 8 hours of work to purchase a bicycle in 2003 .

One result of this increase in relative wealth is the greater availability of leisure time to consumers. To this end Fogel (2000: 185) states that the average American worker laboured 3 069 hours per year in 1870 (six 10-hour days per week), compared to 1730 hours per year currently. This reduction in the number of hours worked per week, combined with fulltime education until a higher age than in the $19^{\text {th }}$ century and increased life expectancy, have led to a situation where "[f]rom 1880 to 1990 , the average American's life-long spare time increased from 48300 hours to 246000 hours" (Marber, 2003: 147). The implication is that the work/leisure time balance could also have shifted in favour of labour over the periods of comparison, but no allowance is made for increases in leisure time or decreases in the number of hours of work required to afford any particular purchase.

\section{4}

Comparison of actual and estimated prices over different periods

This section compares the actual prices of similar items with prices estimated to have increased in accordance with the rate of inflation over different periods between 1974 and 2006. For the purpose of this analysis, historic price data were obtained from the Institute for Planning Research, an Institute at the University of Port Elizabeth which subsequently merged with other institutions of higher learning to form the Nelson Mandela Metropolitan University. The Institute calculated minimum living wages for different income groups on an annual basis from 1974 (Institute for Planning Research, (SA). The prices of groceries (household consumables, including food), clothing and footwear are available from that date. Records are available until 2004, when it was decided to discontinue the research. In collecting price data, the Institute recorded the cheapest prices for the purpose of comparison.

In the interest of similar comparisons in future, it was decided to sample prices of groceries at the same shop used for sampling purposes in respect of the price data reported in Rossouw and Padayachee (2006). To this end, price information on items included in the surveys of the Institute was collected at Shoprite in Silverton in Pretoria, wherever possible. Since this shop specialises in groceries, prices for clothing and footwear were collected at Ackermans, Mr Price and Pep Stores in the same shopping mall.

The actual sample survey data for 1974 , 1984, 1994 and 2004 were obtained from the Institute for the purpose of comparative research. The data reflecting the prices per item for these periods are summarised in appendices 1 to 4 . Price data are adjusted for comparative purposes so as to estimate current prices in 2006 by means of annual CPI figures from the respective base years. The results are summarised in appendices 1 to 4 , with the data for 1974, 1984, 1994 and 2004 forming the four base periods of comparison. 
In total, the prices of 47 items could be used in the analysis of price movements over the period of 32 years. Not all the price data could be employed for the full period of comparison. The estimated and actual prices of items could therefore be compared 170 times, rather than 188 times $(47 \times 4)$ as would have been the case if all prices were available for the full period of comparison. The analysis over all four periods of comparison indicates that certain actual prices exceed estimated prices, but that in other instances estimated prices exceed actual prices, implying that changes in the CPI "overmeasured" the rate of price increases in those instances. Of the 170 price comparisons, 105 actual prices (or 61.8 per cent of the prices) are lower than the estimated prices, while 65 prices (or 38.2 per cent of the prices) are higher. Based on this data, the IAI can be calculated as follows:

$$
\begin{aligned}
\text { IAI } & =\left[\left(0-\mathrm{P}_{\mathrm{g}}\right)+\left(0+\mathrm{P}_{\mathrm{s}}\right)\right] \\
& =[(0-38,2)+(0+61,8)] \\
& =23,6 .
\end{aligned}
$$

This result indicates that, over the periods of comparison, more prices increased at a rate slower than the rate of inflation than at a rate faster than the rate of inflation. No systematic trend of actual prices exceeding estimated prices is discernable over this period of 32 years, therefore indicating no basis for low inflation credibility as was reported in Rossouw and Padayachee (2007). The two most noteworthy trends over the period of comparison are that the actual prices of:

- clothing and footwear (with a current weight of 3.25 per cent in the CPI basket) are generally lower than the price levels estimated in terms of the CPI; and

- household consumables (mainly household cleaning material) with a current weight of 1.25 per cent in the CPI basket, often exceeded estimated prices.

Actual prices of certain categories of items exceeding price levels estimated in terms of changes in the CPI (e.g. household consumables in this analysis) have implications for the public's perceptions about the accuracy of inflation data, as this might erode the credibility of published inflation figures. This is related to differences between the inflation perceptions of men and women (see for instance Brachinger, 2005; Bryan \& Ventaku, 2001a; Bryan \& Ventaku, 2001b; or Palmqvist \& Stromberg, 2004). Jonung (1981: 968) states that these differences are generally caused by a larger increase in food prices than in the general price level. As women are responsible for the major share of food purchases, men are less exposed to movements in food prices, thereby showing “... that perceived rates are influenced by individual expenditure patterns" (Jonung, 1981: 968).

Low credibility of inflation figures despite their general accuracy in reporting average price increases in an economy might eventually jeopardise an inflation-targeting monetary policy framework. With a lack of credibility in the accuracy of inflation figures, the general public might conclude that monetary policy aiming at the achievement of an inflation target brings only the pain of high interest rates without the tangible benefits of lower inflation.

\section{5}

\section{Conclusions}

Over the period of comparison no systematic over- or under-reporting of changes in prices in terms of the CPI was discernible. As should be expected with adjustments reflecting average price increases, the actual prices of some goods and services were lower than the estimated prices, while the actual prices of other goods and services exceeded estimated prices. Based on this analysis, no foundation for a low credibility of inflation figures as an accurate indication of average price increases in the South African economy could be found. The methodology employed in this analysis is suitable for future use to revalidate the accuracy of inflation figures, using the price data reported in this note.

In respect of household consumption goods, the actual prices of some items are much higher than their estimated price levels, based on historic prices adjusted for CPI. This could provide a reason for low-income earners spending disproportionately on these goods to 
attach less credibility to inflation figures than high-income earners. In as much as the spending patterns of housewives correspond to a larger degree with the spending patterns of low income earners than with average spending patterns, this finding provides some basis for the credibility of inflation figures to differ between genders. Insofar as recent purchasing experiences contribute to low inflation credibility, monetary policy aiming at the achievement of the inflation target might not be supported by the general public on the grounds that it does not reduce inflation.

A precondition for the efficient functioning of a market in any economy is that producers and consumers must be able to identify changes in the relative prices of goods and services over time. The identification of such changes allows producers and consumers to take appropriate economic decisions in the allocation of productive resources and in determining consumption expenditure, respectively. Producers and consumers will take decisions not only to their own detriment, but also to the detriment of the economic system as a whole, if they cannot distinguish between increasing prices reflecting changes in relative scarcity and price increases owing to an ongoing inflationary process. Although the present analysis highlights, to some degree, relative price changes over the period of comparison that are not immediately obvious to consumers, this aspect could be expanded in future research into inflation accuracy.

Based on available data, an IAI was calculated. Despite its shortcomings, it can be utilised to enhance inflation credibility, particularly because it is easy to understand. If calculated periodically, it could serve as a benchmark for the measurement of inflation accuracy. In further research some modifications to the IAI might be considered, for example, in respect of the items to be included; the period or periods of comparison; the treatment of changes in relative scarcity and quality improvements; the allocation of spending weights to items used to analyse price changes; and the identification of historic prices of services to compare, since expenditure on services currently accounts for some 40 per cent of household spending in terms of the composition of the CPI (Statistics SA, 2003).

The research reported in this note confirms the hypothesis that changes in the domestic consumer price index (CPI) do fairly reflect average price increases over time. However, the confirmation of this hypothesis does not prevent the distortion of perceptions about the accuracy of inflation figures. Inflation credibility is more likely than not influenced by the most recent purchasing experiences of consumers, as no systematic basis for low inflation credibility is established by the analysis in this note.

\section{Endnotes}

1 The framework, theory and methodology used in this note draw on the $\mathrm{PhD}$ thesis by Jannie Rossouw, completed under the supervision of Prof Vishnu Padayachee at the School of Development Studies at the University of KwaZulu-Natal. Please see Rossouw (2008) in this regard. The views and opinions expressed in this note do not necessarily reflect the views and opinions of the SA Reserve Bank or any of the Universities. Comments and assistance of Mr Fanie Joubert of the Efficient Group and Ms Adél Bosch of the SA Reserve Bank on some aspects of this note is gratefully acknowledged.

2 Although food as such might have remained fairly homogeneous, the quality of food packaging and presentation (e. g. the introduction of sliced bread) improved considerably during the review period, i.e. since 1974.

\section{References}

1 ALBAGLI, E. \& SCHMIDT-HEBBEL, K. (2004) "By how much and why do inflation targeters miss their targets", paper presented at the conference of the Federal Reserve Bank of Atlanta on the role of inflation targeting in strategies for implementing monetary policy in the Americas.

2 BRACHINGER, H.W. (2005) "Measuring perceived inflation: a prospect theory approach", International Statistical Institute, Voorburg, The Netherlands. $55^{\text {th }}$ session in Sydney, Australia. 5 to 12 April.

3 BRYAN, M.F. \& VENTAKU, G. (2001a) “The curiously different inflation perspectives of men and women", Economic Commentary, Federal Reserve Bank of Cleveland. November. 
4 BRYAN, M.F. \& VENTAKU, G. (2001b) "The demographics of inflation opinion surveys", Economic Commentary, Federal Reserve Bank of Cleveland. October.

5 CALDERON, C. \& SCHMIDT-HEBBEL, K. (2003) "Macroeconomic policies and performance in Latin America", Journal of International Money and Finance. 22(5). December.

6 COX, W.M. \& ALM, R. (1997) "Time well spent: The declining real cost of living in America", Annual Report of the Federal Reserve Bank of Dallas, Federal Reserve Bank: Dallas.

7 FOGEL, R.W. (2000) The Fourth Awakening and the Future of Egalitarianism, University of Chicago Press: Chicago.

8 GRAY, G. (2000) "Modelling the second stage of transition from communism: A closer look at the Balkans", MOCT-MOST: Economic Policy in Transitional Economies, 10(2) June.

9 INSTITUTE FOR PLANNING RESEARCH [Sa] "The household subsistence level in the major urban centres of the Republic of South Africa", October 1974; September 1984; September 1994; and August 2004. University of Port Elizabeth.

10 JONUNG, L. (1981) "Perceived and expected rates of inflation in Sweden”, American Economic Review. 7(5). December.

11 MARBER, P. (2003) Money Changes Everything - How Global Prosperity is Reshaping our Needs, Values and Lifestyle, Prentice Hall: New Jersey.

12 MISHKIN, F.S. \& SCHMIDT-HEBBEL, K. (2007) "Does inflation targeting make a difference?", Working Paper 12876, National Bureau of Economic Research. January.

13 PALMQVIST, S. \& STROMBERG, L. (2004) "Households' inflation opinions - a tale of two surveys", Economic Review, 4. [Online].

14 http://www.riksbank.com/upload/Dokument riksbank/Kat_publicerat/Artiklar_PV/ER04_2.pd [Accessed on 19 July 2005].

15 ROGER, S. \& STONE, M. (2005) "On target? The international experience with achieving inflation targets", Working paper 05/163. International Monetary Fund: Washington.

16 ROSSOUW, J. (2008) "Inflation in South Africa: 1921 to 2006. History, measurement and credibility", Unpublished PhD thesis. University of KwaZulu-Natal: Durban.

17 ROSSOUW, J. \& JOUBERT, F. (2005a) "A perspective on inflation credibility", South African Journal of Economic and Management Science, 8(4). December.

18 ROSSOUW, J. \& JOUBERT, F. (2005b) "Supporting an inflation-targeting policy with the measurement of inflation credibility", South African Journal of Economics, 73(2). June.

19 ROSSOUW, J. \& PADAYACHEE, V. (2006) "Testing inflation credibility: South African inflation and price changes since 1921", SA Reserve Bank Discussion Paper DP/09/06. SA Reserve Bank: Pretoria.

20 ROSSOUW, J. \& PADAYACHEE, V. (2007) "A study on inflation credibility among students at the University of Pretoria”, South African Journal of Economic and Management Sciences, 10(1). March.

21 SA RESERVE BANK Website. [Online].http:// www.reservebank.co.za [Accessed on various dates].

22 STATISTICS SA (2003) "Consumer price index - detailed weights: historical metropolitan and other urban areas", P0141.5. 30 May.

\section{Personal visits to shops}

ACKERMANS, SILVERTON (SA). Personal visit. 4 December 2006.

MR PRICE, SILVERTON (SA). Personal visit. 4 December 2006.

PEP STORES, SILVERTON (SA). Personal visit. 4 December 2006.

SHOPRITE, SILVERTON (SA). Personal visit. 4 December 2006. 


\section{APPENDIX 1}

Table 1

Comparison of actual and estimated prices of selected goods, 1974 to 2006 (all prices in R)

\begin{tabular}{|c|c|c|c|c|}
\hline & Adjusted unit & Actual price & Actual prices* & $\begin{array}{c}\text { Prices estimated ito } \\
\text { CPI (a) }\end{array}$ \\
\hline & & 1974 & 2006 & 2006 \\
\hline CPI $(1974=100)$ & & 100.0 & & 2463,0 \\
\hline \multicolumn{5}{|c|}{ Food } \\
\hline Brown bread & $800 \mathrm{~g}$ & 0.09 & 3.69 & 2.21 \\
\hline Cheese & $1 \mathrm{~kg}$ & 0.98 & 31.99 & 24.13 \\
\hline Coffee/tea & $1 \mathrm{~kg}(50 / 50)$ & 0.98 & 32.98 & 24.13 \\
\hline Cooking oil & $750 \mathrm{ml}$ & 0.46 & 6.99 & 11.33 \\
\hline Dry legumes & $500 \mathrm{~g}$ & 0.31 & 4.39 & 7.63 \\
\hline Eggs & $1 \mathrm{doz}$ & 0.40 & 8.04 & 9.85 \\
\hline Maize meal & $12.5 \mathrm{~kg}$ & 1.34 & 31.99 & 33.00 \\
\hline Margarine & $250 \mathrm{~g}$ & 0.15 & 2.89 & 3.70 \\
\hline Salt & $1 \mathrm{~kg}$ & 0.13 & 2.99 & 3.20 \\
\hline Skimmed milk & $500 \mathrm{~g}$ & 0.61 & 21.99 & 15.02 \\
\hline Sugar & $2.5 \mathrm{~kg}$ & 0.41 & 11.29 & 10.10 \\
\hline Sub-total & & 5.86 & 159.23 & 144.33 \\
\hline \multicolumn{5}{|c|}{ Male clothing } \\
\hline Pullover (c) & 1 & 4.69 & 49.99 & 115.51 \\
\hline Pyjamas (b) & Long pair & 4.99 & 69.95 & 122.91 \\
\hline Shirts & long sleeve & 3.50 & 39.99 & 86.20 \\
\hline Shoes & 1 pair & 4.50 & 59.99 & 110.83 \\
\hline Socks & 1 pair & 0.65 & 4.99 & 16.01 \\
\hline Trousers & 1 pair & 8.99 & 59.99 & 221.41 \\
\hline Underpants & 1 pair & 0.99 & 6.49 & 24.39 \\
\hline Vest & 1 & 0.99 & 17.99 & 24.39 \\
\hline Sub-total & & 24.60 & 309.38 & 726.50 \\
\hline \multicolumn{5}{|c|}{ Female clothing } \\
\hline Blouse & 1 & 3.99 & 22.99 & 98.27 \\
\hline Bra & 1 & 1.19 & 9.99 & 29.31 \\
\hline Cotton dress (b) & 1 & 5.66 & 69.95 & 139.41 \\
\hline
\end{tabular}


SAJEMS NS 11 (2008) No 2

\begin{tabular}{|c|c|c|c|c|}
\hline Head scarf & 1 & 0.48 & 16.99 & 11.82 \\
\hline Jersey (b) & 1 & 5.99 & 79.00 & 147.54 \\
\hline Night dress & Summer & 3.59 & 29.00 & 88.43 \\
\hline Overcoat & 1 & 18.00 & 39.95 & 443.34 \\
\hline Panties & 1 pair & 0.49 & 4.99 & 12.07 \\
\hline Petticoat & 1 & 1.99 & 16.99 & 49.01 \\
\hline Shoes & 1 pair & 4.29 & 29.99 & 105.67 \\
\hline Skirt & 1 & 3.99 & 29.99 & 98.27 \\
\hline Stockings & 1 pair & 0.33 & 4.99 & 8.13 \\
\hline Vest & 1 & 0.99 & 12.99 & 24.39 \\
\hline Sub-total & & & 367.81 & 1255.64 \\
\hline \multicolumn{5}{|c|}{ Household consumables } \\
\hline Bleach & $750 \mathrm{ml}$ & 0.16 & 5.29 & 3.94 \\
\hline Floor polish & $400 \mathrm{ml}$ & 0.19 & 9.59 & 4.67 \\
\hline Scouring powder & $550 \mathrm{~g}$ & 0.15 & 7.69 & 3.70 \\
\hline Shoe polish & $50 \mathrm{ml}$ & 0.13 & 5.19 & 3.20 \\
\hline Soap powder & $1 \mathrm{~kg}$ & 0.59 & 12.99 & 14.53 \\
\hline Sunlight soap & $500 \mathrm{~g}$ & 0.27 & 5.99 & 6.65 \\
\hline Sub-total & & 1.49 & 46.74 & 36.70 \\
\hline
\end{tabular}

* Italics denote actual prices lower than estimated CPI prices; bold denotes actual prices higher than estimated CPI prices Sources: See appendix 4 


\section{APPENDIX 2}

\section{Table 2}

Comparison of actual and estimated prices of selected goods, 1984 to 2006 (all prices in R) Table $2 a$ Average prices of food items

\begin{tabular}{|c|c|c|c|c|}
\hline & Adjusted unit & Actual price & Actual prices* & $\begin{array}{c}\text { Prices estimated } \\
\text { ito CPI (a) }\end{array}$ \\
\hline & & 1984 & 2006 & 2006 \\
\hline CPI $(1984=100)$ & & 100.0 & & 748.8 \\
\hline Brown bread & $800 \mathrm{~g}$ & 0.32 & 3.69 & 2.40 \\
\hline Cheese & $1 \mathrm{~kg}$ & 5.49 & 31.99 & 41.10 \\
\hline Coffee/tea & $1 \mathrm{~kg}(50 / 50)$ & 4.06 & 32.98 & 30.41 \\
\hline Cooking oil & $750 \mathrm{ml}$ & 1.86 & 6.99 & 13.93 \\
\hline Dry legumes & $500 \mathrm{~g}$ & 0.86 & 4.39 & 6.45 \\
\hline Eggs & $1 \mathrm{doz}$ & 1.06 & 8.04 & 7.93 \\
\hline Maize meal & $12.5 \mathrm{~kg}$ & 5.79 & 31.99 & 43.35 \\
\hline Margarine & $250 \mathrm{~g}$ & 0.41 & 2.89 & 3.07 \\
\hline Salt & $1 \mathrm{~kg}$ & 0.42 & 2.99 & 3.15 \\
\hline Skimmed milk & $500 \mathrm{~g}$ & 1.89 & 21.99 & 14.15 \\
\hline Sugar & $2.5 \mathrm{~kg}$ & 2.02 & 11.29 & 15.12 \\
\hline Sub-total & & 24.18 & 159.23 & 181.07 \\
\hline \multicolumn{5}{|c|}{ Items with prices available from 1984 to 2006} \\
\hline Jam & $900 \mathrm{~g}$ & 1.20 & 9.99 & 8.99 \\
\hline Red meat & $1 \mathrm{~kg}$ & 2.78 & 28.99 & 20.81 \\
\hline
\end{tabular}


Table $2 b$ Average prices of clothing

\begin{tabular}{|c|c|c|c|c|}
\hline & Adjusted unit & Actual price & Actual prices* & $\begin{array}{c}\text { Prices estimated } \\
\text { ito } \mathrm{CPI}(\mathrm{a})\end{array}$ \\
\hline & & 1984 & 2006 & 2006 \\
\hline CPI $(1984=100)$ & & 100.0 & & 748.8 \\
\hline \multicolumn{5}{|c|}{ Male clothing } \\
\hline Pullover (c) & 1 & 6.60 & 49.99 & 49.45 \\
\hline Pyjamas (b) & Long pair & 10.55 & 69.95 & 80.00 \\
\hline Shirts & long sleeve & 8.24 & 39.99 & 61.70 \\
\hline Shoes & 1 pair & 9.90 & 59.99 & 74.14 \\
\hline Socks & 1 pair & 1.20 & 4.99 & 8.99 \\
\hline Trousers & 1 pair & 15.39 & 59.99 & 115.25 \\
\hline Underpants & 1 pair & 1.81 & 6.49 & 13.55 \\
\hline Vest & 1 & 2.74 & 17.99 & 20.52 \\
\hline Sub-total & & 56.43 & 309.38 & 422.56 \\
\hline \multicolumn{5}{|c|}{ Female clothing } \\
\hline Blouse & 1 & 7.69 & 22.99 & 57.58 \\
\hline Bra & 1 & 2.25 & 9.99 & 16.85 \\
\hline Cotton dress (b) & 1 & 9.16 & 69.95 & 68.60 \\
\hline Head scarf & 1 & 1.97 & 16.99 & 14.75 \\
\hline Jersey (b) & 1 & 8.79 & 79.00 & 65.82 \\
\hline Night dress & Summer & 8.79 & 29.00 & 65.82 \\
\hline Overcoat & 1 & 54.99 & 39.95 & 411.76 \\
\hline Panties & 1 pair & 1.15 & 4.99 & 8.61 \\
\hline Petticoat & 1 & 4.39 & 16.99 & 32.87 \\
\hline Shoes & 1 pair & 8.79 & 29.99 & 65.82 \\
\hline Skirt & 1 & 7.69 & 29.99 & 57.58 \\
\hline Stockings & 1 pair & 0.80 & 4.99 & 5.98 \\
\hline Vest & 1 & 1.86 & 12.99 & 13.93 \\
\hline Sub-total & & 118.32 & 367.81 & 886.01 \\
\hline
\end{tabular}


Table 2c Average prices of household consumables (c)

\begin{tabular}{|l|c|c|c|c|}
\hline & Adjusted unit & Actual price & Actual prices* & $\begin{array}{c}\text { Prices estimated } \\
\text { ito CPI (a) }\end{array}$ \\
\hline & & $\mathbf{1 9 8 4}$ & $\mathbf{2 0 0 6}$ & $\mathbf{2 0 0 6}$ \\
\hline CPI $(1984=100)$ & & 100.0 & 5.29 & 3.30 \\
\hline Bleach & $750 \mathrm{ml}$ & 0.44 & 9.59 & 7.34 \\
\hline Floor polish & $400 \mathrm{ml}$ & 0.98 & 7.69 & 4.04 \\
\hline Scouring powder & $550 \mathrm{~g}$ & 0.54 & 5.19 & 11.38 \\
\hline Shoe polish & $50 \mathrm{ml}$ & 0.45 & 12.99 & 5.39 \\
\hline Soap powder & $1 \mathrm{~kg}$ & 1.52 & 5.99 & 34.82 \\
\hline Sunlight soap & $500 \mathrm{~g}$ & 0.72 & 46.74 & \\
\hline Sub-total & & 4.65 & & 3.37 \\
\hline
\end{tabular}

* Italics denote actual prices lower than estimated CPI prices; bold denotes actual prices higher than estimated CPI prices Sources: See appendix 4 


\section{APPENDIX 3}

\section{Table 3}

Comparison of actual and estimated prices of selected goods, 1994 to 2006 (all prices in R) Table $3 a$ Average prices of food items

\begin{tabular}{|l|c|c|c|c|}
\hline & Adjusted unit & Actual price & Actual prices* & $\begin{array}{c}\text { Prices estimated } \\
\text { ito CPI (a) }\end{array}$ \\
\hline CPI $(1994=100)$ & & September 1994 & $\mathbf{2 0 0 6}$ & 201.2 \\
\hline Brown bread & $800 \mathrm{~g}$ & 100.0 & & 3.12 \\
\hline Cheese & $1 \mathrm{~kg}$ & 1.55 & 3.69 & 34.18 \\
\hline Coffee/tea & $1 \mathrm{~kg}(50 / 50)$ & 16.99 & 31.99 & 37.57 \\
\hline Cooking oil & $750 \mathrm{ml}$ & 18.68 & 6.99 & 6.00 \\
\hline Dry legumes & $500 \mathrm{~g}$ & 2.98 & 4.39 & 6.21 \\
\hline Eggs & $1 \mathrm{doz}$ & 2.14 & 8.04 & 34.69 \\
\hline Maize meal & $12.5 \mathrm{~kg}$ & 3.09 & 31.99 & 2.21 \\
\hline Margarine & $250 \mathrm{~g}$ & 17.24 & 2.89 & 3.20 \\
\hline Salt & $1 \mathrm{~kg}$ & 1.10 & 2.99 & 14.88 \\
\hline Skimmed milk & $500 \mathrm{~g}$ & 1.59 & 21.99 & 13.24 \\
\hline Sugar & $2.5 \mathrm{~kg}$ & 7.20 & 159.23 & 159.20 \\
\hline Sub-total & & 79.14 & & 29 \\
\hline
\end{tabular}


Table $3 b$ Average prices of clothing

\begin{tabular}{|c|c|c|c|c|}
\hline & Adjusted unit & Actual price & Actual prices* & $\begin{array}{c}\text { Prices estimated } \\
\text { ito CPI (a) }\end{array}$ \\
\hline & & 1994 & 2006 & 2006 \\
\hline \multicolumn{5}{|c|}{ Male clothing } \\
\hline Pullover (c) & 1 & 42.99 & 49.99 & 86.48 \\
\hline Pyjamas (b) & Long pair & 11.39 & 69.95 & 22.91 \\
\hline Shirts & long sleeve & 21.74 & 39.99 & 43.74 \\
\hline Shoes & 1 pair & 39.99 & 59.99 & 80.45 \\
\hline Socks & 1 pair & 5.66 & 4.99 & 11.38 \\
\hline Trousers & 1 pair & 37.49 & 59.99 & 75.41 \\
\hline Underpants & 1 pair & 8.49 & 6.49 & 17.08 \\
\hline Vest & 1 & 10.99 & 17.99 & 22.11 \\
\hline Sub-total & & 178.74 & 309.38 & 359.56 \\
\hline \multicolumn{5}{|c|}{ Female clothing } \\
\hline Blouse & 1 & 24.99 & 22.99 & 50.27 \\
\hline Bra & 1 & 12.49 & 9.99 & 25.12 \\
\hline Cotton dress (b) & 1 & 29.99 & 69.95 & 60.33 \\
\hline Head scarf (b) & 1 & 11.99 & 16.99 & 24.12 \\
\hline Jersey & 1 & 35.19 & 79.00 & 70.79 \\
\hline Night dress & Summer & 19.99 & 29.00 & 40.21 \\
\hline Overcoat & 1 & 32.97 & 39.95 & 66.32 \\
\hline Panties & 1 pair & 5.89 & 4.99 & 11.85 \\
\hline Petticoat & 1 & 26.99 & 16.99 & 54.30 \\
\hline Shoes & 1 pair & 32.99 & 29.99 & 66.37 \\
\hline Skirt & 1 & 25.99 & 29.99 & 52.28 \\
\hline Stockings & 1 pair & 3.66 & 4.99 & 7.36 \\
\hline Vest & 1 & 9.99 & 12.99 & 20.09 \\
\hline Sub-total & & 273.12 & 367.81 & 549.46 \\
\hline
\end{tabular}


Table 3c Average prices of household consumables (all prices in R) (c)

\begin{tabular}{|l|c|c|c|c|}
\hline & Adjusted unit & Actual price & Actual prices* & $\begin{array}{c}\text { Prices estimated } \\
\text { ito CPI (a) }\end{array}$ \\
\hline & & $\mathbf{1 9 9 4}$ & $\mathbf{2 0 0 6}$ & $\mathbf{2 0 0 6}$ \\
\hline Bleach & $750 \mathrm{ml}$ & 1.80 & 5.29 & 3.62 \\
\hline Floor polish & $400 \mathrm{ml}$ & 3.79 & 9.59 & 7.62 \\
\hline Scouring powder & $550 \mathrm{~g}$ & 2.79 & 7.69 & 5.61 \\
\hline Shoe polish & $50 \mathrm{ml}$ & 1.68 & 5.19 & 3.38 \\
\hline Soap powder & $1 \mathrm{~kg}$ & 4.59 & 12.99 & 9.25 \\
\hline Sunlight soap & $500 \mathrm{~g}$ & 2.15 & 5.99 & 4.32 \\
\hline Sub-total & & 16.80 & 46.74 & 33.79 \\
\hline
\end{tabular}

Table 3d Items with prices available from 1994 to 2006

\begin{tabular}{|l|c|c|c|c|}
\hline & Adjusted unit & Actual price & Actual prices* & $\begin{array}{c}\text { Prices estimated } \\
\text { ito CPI (a) }\end{array}$ \\
\hline & & $\mathbf{1 9 9 4}$ & $\mathbf{2 0 0 6}$ & $\mathbf{2 0 0 6}$ \\
\hline Jam & $900 \mathrm{~g}$ & 4.49 & 9.99 & 6.64 \\
\hline Peanut butter & $410 \mathrm{~g}$ & 3.25 & 9.99 & 5.82 \\
\hline Pilchards & $425 \mathrm{~g}$ & 2.89 & 7.49 & 4.80 \\
\hline Potatoes & $1 \mathrm{~kg}$ & 2.39 & 1.69 & 27.40 \\
\hline Red meat & $1 \mathrm{~kg}$ & 13.62 & 28.99 & 8.34 \\
\hline Samp & $2.5 \mathrm{~kg}$ & 4.15 & 8.69 & 9.43 \\
\hline Sunlight liquid & $750 \mathrm{ml}$ & 4.69 & 17.49 & \\
\hline
\end{tabular}

* Italics denote actual prices lower than estimated CPI prices; bold denotes actual prices higher than estimated CPI prices 


\section{APPENDIX 4}

\section{Table 4}

Comparison of actual and estimated prices of selected goods, 2004 to 2006 (all prices in R) Table 4 a Average prices of food items

\begin{tabular}{|c|c|c|c|c|}
\hline & Adjusted unit & Actual price & Actual price* & $\begin{array}{c}\text { Prices estimated } \\
\text { ito CPI (a) }\end{array}$ \\
\hline & & August 2004 & 2006 & 2006 \\
\hline CPI $(2004=100)$ & & 100.0 & & 108.3 \\
\hline Brown bread & $800 \mathrm{~g}$ & 3.59 & 3.69 & 3.88 \\
\hline Cheese & $1 \mathrm{~kg}$ & 32.9 & 31.99 & 35.63 \\
\hline Coffee/tea & $1 \mathrm{~kg}(50 / 50)$ & 31.15 & 32.98 & 33.73 \\
\hline Cooking oil & $750 \mathrm{ml}$ & 5.99 & 6.99 & 6.49 \\
\hline Dry legumes & $500 \mathrm{~g}$ & 4.29 & 4.39 & 4.65 \\
\hline Eggs & $1 \mathrm{doz}$ & 8.98 & 8.04 & 9.72 \\
\hline Maize meal & $12.5 \mathrm{~kg}$ & 29.99 & 31.99 & 32.48 \\
\hline Margarine & $250 \mathrm{~g}$ & 1.85 & 2.89 & 2.01 \\
\hline Salt & $1 \mathrm{~kg}$ & 1.99 & 2.99 & 2.15 \\
\hline Skimmed milk & $500 \mathrm{~g}$ & 23.25 & 21.99 & 25.18 \\
\hline Sugar & $2.5 \mathrm{~kg}$ & 11.99 & 11.29 & 12.98 \\
\hline Sub-total & & 155.97 & 159.23 & 168.91 \\
\hline
\end{tabular}


Table $4 b$ Average prices of clothing

\begin{tabular}{|c|c|c|c|c|}
\hline & Adjusted unit & Actual price & Actual price* & $\begin{array}{c}\text { Prices estimated } \\
\text { ito CPI (a) }\end{array}$ \\
\hline & & August 2004 & 2006 & 2006 \\
\hline \multicolumn{5}{|c|}{ Male clothing } \\
\hline Pullover (c) & 1 & 89.99 & 49.99 & 97.46 \\
\hline Pyjamas (b) & Long pair & 19.99 & 69.95 & 21.65 \\
\hline Shirts & long sleeve & 37.49 & 39.99 & 40.60 \\
\hline Shoes & 1 pair & 69.99 & 59.99 & 75.80 \\
\hline Socks & 1 pair & 6.99 & 4.99 & 7.57 \\
\hline Trousers & 1 pair & 69.99 & 59.99 & 75.80 \\
\hline Underpants & 1 pair & 7.77 & 6.49 & 8.41 \\
\hline Vest & 1 & 9.00 & 17.99 & 9.74 \\
\hline Sub-total & & 474.17 & 309.38 & 337.04 \\
\hline \multicolumn{5}{|c|}{ Female clothing } \\
\hline Blouse & 1 & 29.99 & 22.99 & 32.48 \\
\hline Bra & 1 & 26.99 & 9.99 & 29.23 \\
\hline Cotton dress (b) & 1 & 49.99 & 69.95 & 54.14 \\
\hline Head scarf & 1 & 16.99 & 16.99 & 18.40 \\
\hline Jersey (b) & 1 & 49.99 & 79.00 & 55.14 \\
\hline Night dress & Summer & 49.99 & 29.00 & 54.14 \\
\hline Overcoat & 1 & 62.97 & 39.95 & 68.20 \\
\hline Panties & 1 pair & 9.99 & 4.99 & 10.82 \\
\hline Petticoat & 1 & 29.99 & 16.99 & 32.48 \\
\hline Shoes & 1 pair & 69.99 & 29.99 & 75.80 \\
\hline Skirt & 1 & 49.99 & 29.99 & 54.14 \\
\hline Stockings & 1 pair & 6.32 & 4.99 & 6.85 \\
\hline Vest & 1 & 19.99 & 12.99 & 21.65 \\
\hline Sub-total & & 473.18 & 367.81 & 512.48 \\
\hline
\end{tabular}


Table 4c Household consumables

\begin{tabular}{|l|c|c|c|c|}
\hline & Adjusted unit & Actual price & Actual price* & $\begin{array}{c}\text { Prices estimated } \\
\text { ito CPI (a) }\end{array}$ \\
\hline & & August 2004 & $\mathbf{2 0 0 6}$ & $\mathbf{2 0 0 6}$ \\
\hline Bleach & $750 \mathrm{ml}$ & 4.00 & 5.29 & 4.33 \\
\hline Floor polish & $400 \mathrm{ml}$ & 7.89 & 9.59 & 6.54 \\
\hline Scouring powder & $550 \mathrm{~g}$ & 5.99 & 7.69 & 4.65 \\
\hline Shoe polish & $50 \mathrm{ml}$ & 4.29 & 5.19 & 11.91 \\
\hline Soap powder & $1 \mathrm{~kg}$ & 10.99 & 12.99 & 5.94 \\
\hline Sunlight soap & $500 \mathrm{~g}$ & 5.49 & 5.99 & 41.85 \\
\hline Sub-total & & 38.65 & 46.74 & 6.49 \\
\hline
\end{tabular}

Table 4d Items with prices available from 2004 to 2006

\begin{tabular}{|l|c|c|c|c|}
\hline & Adjusted unit & Actual Price & Actual Price* & $\begin{array}{c}\text { Prices estimated } \\
\text { ito CPI (a) }\end{array}$ \\
\hline Jam & & August 2004 & $\mathbf{2 0 0 6}$ & $\mathbf{2 0 0 6}$ \\
\hline Peanut butter & $900 \mathrm{~g}$ & 10.69 & 9.99 & 11.57 \\
\hline Pilchards & $410 \mathrm{~g}$ & 7.88 & 9.99 & 8.53 \\
\hline Plant protein & $425 \mathrm{~g}$ & 5.99 & 7.49 & 6.49 \\
\hline Potatoes & $200 \mathrm{~g}$ & 4.99 & 3.99 & 5.40 \\
\hline Red meat & $1 \mathrm{~kg}$ & 5.49 & 1.70 & 21.10 \\
\hline Samp & $1 \mathrm{~kg}$ & 19.49 & 28.99 & 8.43 \\
\hline Sunlight liquid & $2.5 \mathrm{~kg}$ & 7.79 & 8.69 & 11.96 \\
\hline Toilet paper & $750 \mathrm{ml}$ & 10.99 & 17.49 & 1.72 \\
\hline
\end{tabular}

* Italics denote actual prices lower than estimated CPI prices; bold denotes actual prices higher than estimated CPI prices

\section{Sources for all appendices:}

(a) Authors' calculations; prices for 1974, 1984, 1994 and 2004 from the Institute for Planning Research (Institute for Planning Research, [S.a.]); CPI data obtained from the SA Reserve Bank, Website. All 2006 prices for food were collected at Shoprite, Silverton. Wherever available, prices of the Shoprite house brand product range (Ritebrand) were used. All prices for clothing and footwear were collected at Pep Stores, Silverton, except where indicated as (b) Ackermans, Silverton; or (c) Mr Price, Silverton. 